\title{
PENGARUH MODEL NUMBERED HEAD TOGETHER \\ TERHADAP HASIL BELAJAR PKN KELAS V SDN 15 PADANG SARAI
}

\author{
Oleh : \\ Poppy Juwita, Dra. Reinita, M.Pd, Dra. Tin Indrawati, M.Pd \\ juwita.poppy@gmail.com , reinita_reinita@yahoo.com , \\ indrawati_tin@yahoo.com
}

\section{PGSD FIP Universitas Negeri Padang}

\begin{abstract}
Abstrak
Penelitian ini bertujuan untuk mengetahui pengaruh model Kooperatif tipe Numbered Head Together (NHT) terhadap hasil belajar PKn siswa di kelas V. Jenis penelitian adalah quasy experiment dalam bentuk nonequivalent control group design. Populasi penelitian ini adalah seluruh siswa kelas V SDN 15 Padang Sarai. Dengan teknik purposive sampling diperoleh kelas $\mathrm{V}_{\mathrm{B}}$ sebagai kelas eksperimen dan kelas $\mathrm{V}_{\mathrm{C}}$ sebagai kelas kontrol. Berdasarkan hasil analisis data menggunakan uji t pada taraf signifikan 0,05 diperoleh $t_{\text {hitung }}>t_{\text {tabel }}$ dengan $t_{\text {hitung }}=2,149$ dan $\mathrm{t}_{\text {tabel }}=1,67$ maka hipotesis $\mathrm{H}_{1}$ diterima.
\end{abstract}

This research aims at finding out the effects of the implementation of the 'Numbered Head Together' model, also known as a Cooperative Learning toward students learning outcomes of the Civics lesson at class V of SDN 15 Padang Sarai. This quasi experiment applied the nonequivalent control group design. The population of this research was all grade V students of SDN 15 Padang Sarai. Class $V_{B}$ was chosen as the experiment class while class $\mathrm{V}_{\mathrm{C}}$ was the control class by using the purposive sampling technique. Based on the data analysis using the t-test with the significant level of 0.05 , it is found that $t_{\text {count }}>t_{\text {tablewith }}$ the score of $\mathrm{t}_{\text {count }}=2.149$ while $\mathrm{t}_{\text {table }}=1.67$. Thus, the $\mathrm{H} 1$ hypotesis is accepted .

Katakunci : model NHT, hasil belajar. 


\section{PENDAHULUAN}

Model kooperatif tipe Numbered Head Together (NHT) merupakan salah satu dari model pembelajaran kooperatif. Model NHT adalah jenis pembelajaran kooperatif yang dirancang untuk mempengaruhi pola interaksi siswa dan dapat menjamin keterlibatan semua siswa dalam kelas.Sebagaimana menurut Taufik (2011:146-147) "NHT adalah suatu model belajar dimana setiap peserta didik diberi nomor kemudian dibuat suatu kelompok kemudian secara acak guru memanggil nomor dari peserta didik".

Model NHT pada pembelajaran Pendidikan Kewarganegaraan (PKn) sangat menanamkan kerja sama dan gotong royong dalam memecahkan atau menyelesaikan masalah untuk mencapai sebuah tujuan bersama. Shoimin (2014:108) mengemukakan langkah-langkah model NHT, yaitu:

1) Siswa dibagi dalam kelompok. Setiap siswa dalam setiap kelompok mendapat nomor, 2) guru memberikan tugas dan masing-masing kelompok mengerjakannya, 3) kelompok mendiskusikan jawaban yang benar dan memastikan tiap anggota kelompok dapat mengerjakannya/ mengetahui jawabannya yang baik, 4) guru memanggil salah satu nomor siswa dan nomor yang dipanggil keluar dari kelompoknya melaporkan atau menjelaskan hasil kerja sama mereka, 5) tanggapan dengan teman yang lain, kemudian guru menunjuk nomor yang lain, 6) kesimpulan.

Selain memiliki langkah-langkah, model NHT juga memiliki beberapa keunggulan. Shoimin (2014:108-109) mengemukakan keunggulan model NHT, antara lain:

1) Setiap siswa menjadi siap, 2) dapat melakukan diskusi dengan sungguh-sungguh, 3) siswa yang pandai dapat mengajari siswa yang kurang pandai, 4) terjadi interaksi secara intens antarsiswa dalam menjawab soal, 5) tidak ada siswa yang mendominasi dalam kelompok karena ada nomor yang membatasi.

Kurniasih (2015:30) mengemukakan keunggulan NHT antara lain:

1) Dapat meningkatkan prestasi belajar siswa, 2) mampu memperdalam pemahaman siswa, 3) melatih tanggung jawab siswa, 4) menyenangkan siswa dalam belajar, 5) mengembangkan rasa ingin tahu siswa, 6) meningkatkan rasa percaya diri siswa, 7) mengembangkan rasa saling memiliki dan kerjasama, 8) setiap siswa termotivasi untuk menguasai 
materi, 9) menghilangkan rasa kesenjangan antara yang pintar dengan tidak pintar, 10) tercipta suasana gembira dalam belajar.

Berdasarkan keunggulan model NHT, dapat disimpulkan bahwa model NHT memiliki peranan yang sangat penting untuk meningkatkan hasil belajar PKn siswa Sekolah Dasar (SD). Penggunaan model NHT menyebabkan pembelajaran yang dilakukan terasa lebih menyenangkan. Jika pembelajaran sudah terasa menyenangkan, maka siswa lebih cepat mengerti dan memahami apa yang dipelajarinya, sehingga hasil belajar siswa pun dapat ditingkatkan.

PKn merupakan salah satu mata pelajaran yang wajib diajarkan di SD, karena pembelajaran PKn sangat berpengaruh dalam membentuk karakter siswa. Materi menjaga keutuhan NegaraKesatuan Republik Indonesia (NKRI) pada pembelajaran PKn merupakan salah satu materi yang diajarkan di kelas V SD pada semester I, sesuai dengan Kurikulum Tingkat Satuan Pendidikan (KTSP) pada Standar Kompetensi 1. Memahami pentingnya keutuhan NKRI dengan Kompetensi Dasar 1.3. Menunjukkan contoh-contoh perilaku dalam menjaga keutuhan NKRI. Materi ini menuntut siswa untuk saling berinteraksi dengan siswa lainnya di dalam kelas agar terjalin kerjasama dalam menyelesaikan permasalahan yang terdapat pada materi menjaga keutuhan NKRI.

Berdasarkan observasi yang peneliti lakukan di SDN 15 Padang Saraipada tanggal 2 Agustus 2017peneliti menemukan permasalahan yang berasal dari guru diantaranya 1) Guru dalam pembelajaran kurang melibatkan siswa secara aktif dalam interaksi belajar mengajar, sehingga siswa kurang termotivasi dalam belajar, 2) Guru dalam mengajarkan materi kurang memberikan keterhubungan antara materi dengan fenomena yang ada di lingkungan sekitar siswa, 3) Kurangnya bimbingan guru pada saat diskusi kelompok.

Masalah yang peneliti temui di atas, memberikan dampak terhadap siswa seperti : 1) Siswa kurang memahami konsep pada materi, 2) Siswa kurang aktif dalam menyampaikan pendapat pada saat diskusi kelompok, bertanya dan menjawab pertanyaan guru ketika kegiatan belajar mengajar berlangsung. Hal tersebut menunjukkan bahwa pembelajaran PKn dirasakan kurang menarik bagi siswa, sehingga mengakibatkan pengetahuan siswa menjadi lemah. Dengan 
lemahnya pengetahuan yang dimiliki oleh siswa nantinya akan berdampak buruk terhadap hasil belajar siswa.

Berdasarkan alasan-alasan tersebut peneliti ingin melakukan penelitian dengan menggunakanmodel kooperatif tipe NHT pada pembelajaran PKn. Karena model kooperatif tipe NHT dapat mendorong siswa untuk aktif dalam pembelajaran serta memberikan kesempatan kepada siswa untuk saling membagikan ide-ide dan mempertimbangkan jawaban yang paling tepatyang nantinya akan berdampak baik terhadap hasil belajar siswa.

\section{METODOLOGI}

Dalam penelitian ini, digunakan pendekatan kuantitatif dalam jenis penelitian eksperimen. Dalam Sugiyono (2017:77) menyatakan bahwa "penelitian eksperimen adalah penelitian yang adanya perlakuan atau treatment yang digunakan untuk mencari pengaruh perlakuan tertentu terhadap yang lain dalam kondisi yang terkendalikan."

Penelitian eksperimen yang akan dilakukan yaitu Quasy Eksperiment design (eksperimen semu). Penelitian ini menggunakan dua kelas sampel yaitu kelas eksperimen dan kelas kontrol dimana akan diberi perlakuan yang berbeda dengan materi atau bahan ajar yang sama. Sebelum diberi perlakuan yang berbeda terlebih dahulu kedua kelas sampel diberi tes awal untuk mengetahui keadaan awal adakah perbedaan antara kelompok eksperimen dan kelompok kontrol. Pada setiap akhir pembelajaran diberi tes akhir. Tujuannya adalah untuk mengetahui ada tidaknya pengaruh signifikan penggunaan model kooperatif tipe NHT terhadap hasil belajar PKn siswa dari kedua kelas sampel setelah diberi perlakuan yang berbeda, yaitu dengan cara membandingkan hasil belajar kelas eksperimen dengan kelas kontrol.

Populasi dalam penelitian ini adalah seluruh siswa di kelas V SDN 15 Padang Sarai kota Padang. Teknik pengambilan sampel pada penelitian adalah dengan cara purposive sampling. Purposive samplingadalah teknik penentuan sampel dengan pertimbangan tertentu (Sugiyono, 2017:85). Oleh karena itu terpilih kelas $\mathrm{V}_{\mathrm{B}}$ sebagai kelas eksperimen dan kelas $\mathrm{V}_{\mathrm{C}}$ sebagai kelas kontrol. 
Penelitian ini dilaksanakan di SDN 15 Padang Sarai dan waktu penelitian dilaksanakan pada semester ganjiltahun ajaran 2017/2018. Penelitian ini memiliki variabel yang menjadi perhatian utama yaitu variabel bebas dan variabel terikat. Variabel bebas pada penelitian ini adalah variabel yang kedudukannya memberi pengaruh terhadap variabel terikat dengan cara diberi perlakuan pada sampel peneltian yaitu model kooperatif tipe NHT. Sedangkan variabel terikat adalah variabel yang dipengaruhi oleh variabel bebas dimana variabel terikat pada penelitian ini adalah hasil belajar PKn. Jenis data pada penelitian ini adalah jenis data kuantitatif yang digunakan untuk menjawab rumusan masalah dan hipotesis penelitian tentang hasil belajar PKn siswa.

Instrumen penelitian yang digunakan adalah soal tes hasil belajar. Soal tes hasil belajar berupa tes. Tes disusun berdasarkan kisi-kisi pada indikator yang terdapat dalam materi yang dipelajari. Suatu tes dikatakan layak digunakan atau belum maka ada beberapa hal yang perlu dianalisa dari soal-soal tersebut meliputi, validitas item tes hasil belajar, daya pembeda, indeks kesukaran tes, dan realibilitas soal.

Tes akhir akan diberikan pada kedua kelas sampel untuk menentukan hasil belajar PKn siswa.Teknik analisis data menggunakan uji t yang dilaksanakan setelah uji prasyarat analisis t-tes telah terpenuhi, rumus t-tes yang digunakan sebagai berikut:

$$
\begin{aligned}
& \mathrm{t}=\frac{\bar{x}_{1}-\bar{x}_{2}}{S \sqrt{\frac{1}{n_{1}}+\frac{1}{n_{2}}}} \\
& \text { dimana: } \\
& \mathrm{S}=\sqrt{\frac{\left(n_{1}-1\right) S_{1}^{2}+\left(n_{2}-1\right) S_{2}^{2}}{n_{1}+n_{2}-2}}
\end{aligned}
$$

Untuk keperluan pengujian hipotesis, diperlukan rumus hipotesis statistik yaitu pada taraf signifikan $\alpha=0,05(5 \%)$ dengan hipotasis yang akan diuji: 
$\mathrm{H}_{0}$ :Tidak terdapat pengaruh positifpenerapan model kooperatif tipe Numbered Head Together (NHT) terhadap hasil belajar PKn siswa di kelas V SDN 15 Padang Sarai.

$\mathrm{H}_{1}$ :Terdapat pengaruh positif penerapan model kooperatif tipe Numbered Head Together (NHT) terhadap hasil belajar PKn siswa di kelas V SDN 15 Padang Sarai.

Dengan kriteria pengujian :

Jika $\mathrm{t}_{\text {hitung }}<\mathrm{t}_{\text {tabel }}$ maka $\mathrm{H}_{0}$ diterima dan $\mathrm{H}_{1}$ ditolak

Jika $\mathrm{t}_{\text {hitung }}>\mathrm{t}_{\text {tabel }}$ maka $\mathrm{H}_{0}$ ditolak dan $\mathrm{H}_{1}$ diterima

\section{HASIL PENELITIAN}

\section{A. Deskripsi Data Hasil Penelitian}

\section{Deskripsi data hasil pretest}

Untuk melihat nilai pre-test hasil belajar PKn kelas eksperimen dan kelas kontrol bisa dilihat rekapitulasinya pada tabel 1 di bawah ini:

Tabel 1. Rekapitulasi pre-test kelas eksperimen dan kelas kontrol

\begin{tabular}{|c|c|c|}
\hline \multirow{2}{*}{ Variabel } & \multicolumn{2}{|c|}{ Pre-test } \\
\cline { 2 - 3 } & Kelas Eksperimen & Kelas Kontrol \\
\hline N & 34 & 34 \\
\hline Nilai Tertinggi & 96 & 96 \\
\hline Nilai Terendah & 42 & 30 \\
\hline Mean & 73,65 & 76,65 \\
\hline SD & 16,45 & 14,32 \\
\hline SD $^{2}$ & 270,60 & 205,06 \\
\hline
\end{tabular}

Berdasarkan tabel 1 di atas, kelas eksperimen dengan jumlah anak 34 orang memperoleh nilai tertinggi 96 dan nilai terendah 42. Dari nilai kelas eksperimen diperoleh rata-rata nilai sebesar 73,65 standar deviasi 16,45 dan nilai varians 270,60. Sedangkan kelas kontrol dengan jumlah anak 34 orang memperoleh nilai tertinggi 96 dan nilai terendah 30. Dari nilai kelas kontrol diperoleh rata-rata nilai sebesar 76,65, standar deviasi 14,32 dan nilai varians 205,06. 
Berdasarkan deskripsi hasil pre-test pada tabel di atas, dapat diketahui hasil belajar kelas eksperimen lebih rendah daripada kelas kontrol. Untuk lebih jelasnya dapat dilihat pada grafik 1 berikut:

\section{Grafik 1. Grafik Batang Perbandingan Hasil Pre-test Kelas Sampel}

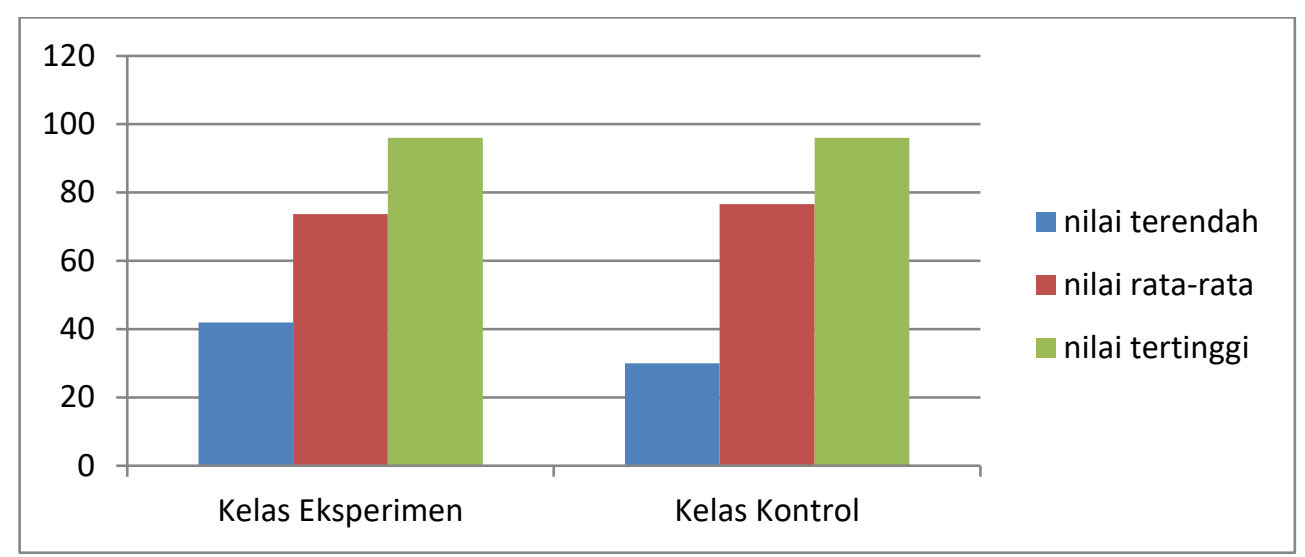

\section{Deskripsi data hasil post-test}

Untuk melihat nilai post-test hasil belajar PKn kelas eksperimen dan kelas kontrol bisa dilihat rekapitulasinya pada tabel 2 dibawah ini:

Tabel 2. Rekapitulasi hasil post-testkelas eksperimen dan kelas kontrol

\begin{tabular}{|c|c|c|}
\hline \multirow{2}{*}{ Variabel } & \multicolumn{2}{|c|}{ Post-test } \\
\cline { 2 - 3 } & Kelas Eksperimen & Kelas Kontrol \\
\hline $\mathrm{N}$ & 34 & 34 \\
\hline Nilai Tertinggi & 100 & 100 \\
\hline Nilai Terendah & 61 & 50 \\
\hline Mean & 87,00 & 81,97 \\
\hline SD & 10,71 & 10,62 \\
\hline SD $^{2}$ & 114,70 & 112,78 \\
\hline
\end{tabular}

Berdasarkan tabel 2 di atas, kelas eksperimen dengan jumlah anak 34orang memperoleh nilai tertinggi 100 dan nilai terendah 61. Dari nilai kelas eksperimen diperoleh rata-rata nilai sebesar 87,00, standar deviasi 10,71 dan nilai varians 114,70. Sedangkan kelas kontrol dengan jumlah anak 34 orang memperoleh nilai tertinggi 100 dan nilai terendah 50. Dari nilai kelas kontrol diperoleh rata-rata nilai sebesar 81,97, standar deviasi 10,62 dan nilai varians 112,78 . 
Berdasarkan deskripsi hasil post-test pada tabel diatas, dapat diketahui hasil belajar PKn kelas eksperimen lebih tinggi daripada kelas kontrol. Untuk lebih jelasnya dapat dilihat pada grafik 2 berikut:

\section{Grafik 2. Grafik Batang Perbandingan Hasil Post-test Kelas Sampel}

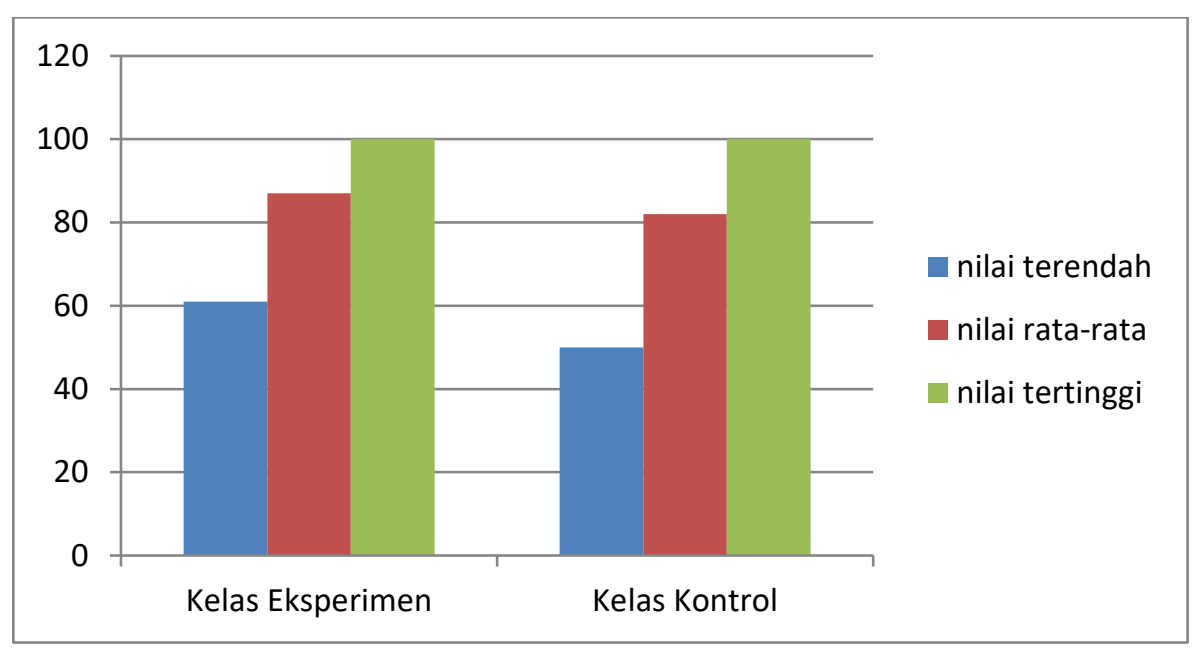

\section{Deskripsi data perbandingan hasil pretest dan postest}

Perbandingan nilai pretest dan postest antara kelompok kontrol dan kelompok eksperimen dapat dilihat pada tabel 3 di bawah ini.

Tabel 3. Perbandingan nilai pretest dan postest kelompok eksperimen dan kelompok kontrol

\begin{tabular}{|c|c|c|c|c|}
\hline \multirow{2}{*}{ No } & \multirow{2}{*}{ Kelompok } & \multicolumn{2}{|c|}{ Nilai rata-rata } & \multirow{2}{*}{ Peningkatan } \\
\cline { 3 - 4 } & & Pretest & Postest & \\
\hline 1. & Eksperimen & 73,65 & 87,00 & 13,35 \\
\hline 2. & Kontrol & 76,65 & 81,97 & 5,32 \\
\hline
\end{tabular}

Berdasarkan tabel 3 di atas perbandingan nilai pretest dan postest kelompok kontrol dan kelompok eksperimen di atas dapat disajikan pada grafik 3 berikut:

Grafik 3. Diagram batang perbandingan nilai pretestdan postestkelompok eksperimen dan kelompok kontrol

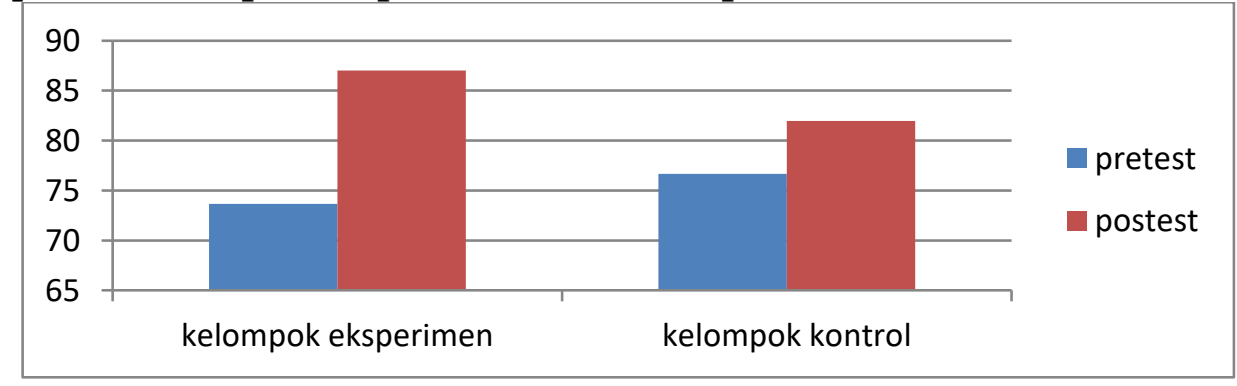




\section{B. Uji Persyaratan Analisis}

Uji persyaratan analisis dilakukan untuk melihat kesimpulan tentang data yang diperoleh dari hasil belajar siswa pada kedua kelas sampel. Sebelum melakukan uji hipotesis menggunakan rumus t-test terlebih dahulu dilakukan uji normalitas dan uji homogenitas variansi.

\section{Uji Normalitas Data}

Uji normalitas bertujuan untuk melihat data hasil belajar kedua kelas sampel berdistribusi normal atau tidak. Untuk melakukan uji normalitas dari data tes hasil belajar baik pada kelas eksperimen maupun kelas kontrol digunakan uji Lilliefors. Setelah dilakukan perhitungan data pada kedua kelas sampel, maka diperoleh harga $\mathrm{L}_{0}$ dan $\mathrm{L}_{\mathrm{t}}$ dengan taraf nyata 0,05 sebagai berikut :

Tabel Hasil uji normalitas data dari tes hasil belajar siswa kelas sampel

\begin{tabular}{|l|l|l|l|l|l|}
\hline Kelas sampel & $\mathbf{N}$ & $\mathbf{L}_{\mathbf{0}}$ & $\mathbf{L}_{\mathbf{t}}$ & Kesimpulan & Keterangan \\
\hline Eksperimen & 34 & 0,036794 & 0,151 & $\mathrm{~L}_{0}<\mathrm{L}_{\text {tabel }}$ & Data normal \\
\hline Kontrol & 34 & 0,02277 & 0,151 & $\mathrm{~L}_{0}<\mathrm{L}_{\text {tabel }}$ & Data normal \\
\hline
\end{tabular}

Dari tabel di atas dapat diketahui bahwa untuk kedua kelas sampel harga $\mathrm{L}_{0}<\mathrm{L}_{\mathrm{t}}$, dengan demikian dapat disimpulkan bahwa data tes hasil belajar kedua kelas sampel berdistribusi normal pada tingkat kepercayaan $95 \%$.

\section{Uji Homogenitas Variansi}

Uji homogenitas variansi bertujuan untuk melihat data hasil tes belajar kelas eksperimen dan kelas kontrol mempunyai variansi yang homogen atau tidak. Dalam uji homogenitas digunakan uji F.

Setelah dilakukan perhitungan, diperoleh data dari kedua kelas sampel sebagai berikut:

$\mathrm{F}=\frac{\text { Varians terbesar }}{\text { variansi terkecil }}$

Perhitungan harga $F$ dengan taraf nyata $\alpha=0,05$ dari tabel distribusi $\mathrm{F}$, ternyata diperoleh harga yaitu $\mathrm{F}_{\text {hitung }}<\mathrm{F}_{\text {tabel }} 1,01<1,76$. Dapat 
disimpulkan bahwa data hasil tes akhir kedua kelas sampel memiliki variansi yang homogen pada tingkat kepercayaan $95 \%$.

\section{Pengujian Hipotesis}

Pengujian hipotesis dilakukan uji normalitas dan uji homogenitas variansi diketahui bahwa kedua kelas sampel memiliki data hasil belajar berdistribusi normal dan variansi yang homogen, maka untuk menguji hipotesis digunakan rumus t-tes. Sebelum dilakukan uji t terlebih dahulu dihitung harga simpangan baku gabungan dari data kedua kelompok sampel, yaitu:

$$
\begin{aligned}
& S=\sqrt{\frac{(34-1) 114,78+(34-1) 112,87}{34+34-2}} \\
& S=\sqrt{113,825} \\
& S_{\text {gabungan }}=10,66
\end{aligned}
$$

Selanjutnya digunakan rumus sebagai berikut :

$$
\begin{aligned}
& \mathrm{t}=\frac{\bar{x}_{1}-\bar{x}_{2}}{\mathrm{~s} \sqrt{\frac{1}{\mathrm{n}_{1}}+\frac{1}{\mathrm{n}_{2}}}} \\
& \mathrm{t}_{\text {hitung }}=\frac{87,00-81,97}{10,66 \sqrt{\frac{1}{34}+\frac{1}{34}}} \\
& \mathrm{t}_{\text {hitung }}=2,149
\end{aligned}
$$

Maka diperoleh $t_{\text {tabel }}$ sebagai berikut:

$$
\begin{aligned}
\mathrm{t}_{\text {tabel }} & =\mathrm{t}_{(1-\alpha)\left(n_{1}+n_{2}-2\right)} \\
& =\mathrm{t}_{(1-0,05)(34+34-2)} \\
& =\mathrm{t}_{(0,95)(66)} \\
& =1,67
\end{aligned}
$$


Jadi, $t_{\text {hitung }}>t_{\text {tabel }}$ dengan 2,149>1,67 maka tolak $\mathrm{H}_{0}$ dan terima $\mathrm{H}_{1}$. Jadi dapat disimpulkan hipotesis dalam penelitian ini diterima yaitu terdapat pengaruh dalam penerapan model NHT terhadap hasil belajar PKn di kelas V SDN 15 Padang Sarai.

\section{PEMBAHASAN}

Model NHT menurut Trianto (2009:82) adalah “jenis pembelajaran kooperatif yang dirancang untuk mempengaruhi pola interaksi siswa dan sebagai alternatif terhadap struktur kelas tradisional." Penerapan model NHT yang dilaksanakan di kelas eksperimen diawali dengan siswa dibagi dalam kelompok dan setiap siswa dalam setiap kelompok mendapatkan nomor masingmasing.Kemudian guru memberikan tugas dan masing-masing kelompok mengerjakannya, semua anggota kelompok mendiskusikan jawaban yang benar dan memastikan tiap anggota kelompok dapat mengerjakannya/ mengetahui jawabannya yang baik. Dalam proses pembelajaran siswa dibimbing dengan diarahkan oleh guru untuk menyelesaikan permasalahan/tugas yang telah diberikan, siswa dituntut lebih banyak melakukan aktivitas belajar dengan kerja kelompok.

Berdasarkan hasil penelitian yang peneliti lakukan di kelas V SDN 15 Padang Sarai, hal di atas memang terbukti. Aktivitas dan hasil belajar siswa yang diperoleh dari kedua kelas sampel, dapat dilihat bahwa terdapat perbedaan hasil belajar siswa dikelas eksperimen yang diajar menggunakan model NHT dengan hasil belajar siswa yang diajar menggunakan pembelajaran konvensional. Berikut ini akan dijelaskan gambaran pembelajaran di kelas eksperimen yang diajar menggunakan model NHT dan gambaran pembelajaran di kelas kontrol yang diajar menggunakan pembelajaran konvensional.

\section{Pembelajaran di kelas eksperimen}

Pembelajaran yang dilaksanakan di kelas eksperimen yang diajar menggunakan model NHT pada awalnya siswa belum mengenal model NHT, tetapi setelah diberi penjelasan dan langkah-langkah tentang model NHT maka siswa dapat memahaminya. Pada pertemuan pertama, siswa belum terbiasa ditunjuk secara acak untuk maju ke depan melaporkan hasil diskusi, dengan 
motivasi dan dorongan yang diberikan oleh guru untuk lebih percaya diri dalam melaksanakan pembelajaran menggunakan model NHT sehingga pada pertemuan kedua siswa memperlihatkan ketertarikan pada proses pembelajaran dengan menggunakan model NHT dengan penguatan dan juga bimbingan yang diberikan oleh guru dalam proses pembelajaran berupa sentuhan,acungan jempol dan katakata semangat memberikan banyak manfaat yang diperoleh siswa. Diantaranya dapat menimbulkan rasa percaya diri dalam proses pembelajaran, siswa merasa lebih dekat dengan teman-temannya dan timbulnya rasa saling menghargai sesama teman disaat bertanya maupun mengemukakan pendapat kepada guru atau temannya dalam proses pembelajaran.

Proses pembelajaran yang dilaksanakan oleh guru menggunakan model NHT dapat mendorong aktivitas siswa sehingga aktivitas cenderung meningkatdisetiap pertemuan, hal ini terbukti banyaknya siswa yang bertanya, mengemukakan pendapat kepada guru atau temannya di dalam kerja kelompok. Setiap kelompok harus menguasai materi yang diberikan setelah memecahkan permasalahan dengan bantuan berupa panduan diskusi.

Keaktifan belajar siswa dalam proses pembelajaran berdampak pada hasil belajar siswa menjadi lebih baik. MenurutShoimin (2014:108) Langkah-langkah model NHT adalah sebagai berikut:

a) Siswa dibagi dalam kelompok. Setiap siswa dalam setiap kelompok mendapat nomor, b) Guru memberikan tugas dan masing-masing kelompok mengerjakannya, c) Kelompok mendiskusikan jawaban yang benar dan memastikan tiap anggota kelompok dapat mengerjakannya/ mengetahui jawabannya yang baik, d) Guru memanggil salah satu nomor siswa dan nomor yang dipanggil keluar dari kelompoknya melaporkan atau menjelaskan hasil kerja sama mereka, e) Tanggapan dengan teman yang lain, kemudian guru menunjuk nomor yang lain, f) Kesimpulan.

Langkah pertama, siswa dibagi dalam kelompok. Setiap siswa dalam setiap kelompok mendapatkam nomor masing-masing. Guru membagi siswa menjadi 7 kelompok karena jumlah siswanya 34 siswa yang tiap kelompok terdiri dari 4-5 siswa, lalu guru membagikan nomor kepada tiap kelompok yang masing-masing anggota kelompok mendapatkan nomor yang berbeda. 
Langkah kedua, guru memberikan tugas dan masing-masing kelompok mengerjakannya. Guru meminta semua anggota kelompok bertanggung jawab dalam menyelesaikan tugas yang diberikan.

Langkah ketiga, kelompok mendiskusikan jawaban yang benar dan memastikan tiap anggota kelompok dapat mengerjakannya/ mengetahui jawabannya yang baik. Hal ini bertujuaan agar setiap anggota kelompok dapat bertukar pikiran untuk mencari jawaban yang baik dan tepat.

Langkah keempat, guru memanggil salah satu nomor siswa dan nomor yang dipanggil keluar dari kelompoknya melaporkan atau menjelaskan hasil kerja sama mereka. Seluruh siswa diharapkan harus siap saat nomornya dipanggil untuk menjelaskan hasil kerja sama kelompok.

Langkah kelima, tanggapan dengan teman yang lain, kemudian guru menunjuk nomor yang lain. Siswa yang nomornya tidak dipanggil, diminta untuk menanggapi hasil laporan dari siswa yang nomornya dipanggil. Setelah itu guru kembali memanggil nomor lain yang belum dipanggil sampai semua nomor dipanggil.

Langkah keenam, kesimpulan. Guru mengarahkan siswa untuk menarik kesimpulan tentang pembelajaran yang baru saja dipelajari.

\section{Pembelajaran di kelas kontrol}

Pembelajaran di kelas kontrol yang diajarkan menggunakan pembelajaran konvensional adalah pembelajaran yang dipakai saat mengajarkan materi menjaga keutuhan NKRI atau pembelajaran yang tidak menggunakan model NHT, dimana guru terlalu banyak berperan sedangkan siswa pada umumnya pasif. Siswa hanya menerima materi yang dijelaskan oleh guru.

Kegiatan pembelajaran menggunakan pembelajaran konvensionalmenekankan pada penyampaian informasi secara verbal dan cendrung searah.Sesuai dengan pendapat Rooijakkers (dalam Boyannese, 2012:2) "pembelajaran konvensionalmerupakan pendekatan pembelajaran satu arah yang berpusat pada guru.Dalam praktiknya, guru sebagai sumber informasi utama yang mengambil peranan sentral dalam pembelajaran." 
Dengan demikian pembelajaran di kelas kontrol yang diajar menggunakan pembelajaran konvensionalmengakibatkan siswa menjadi jenuh dan siswa menjadi pasif dalam pembelajaran di kelas karena hanya sedikit siswa yang mengeluarkan pendapatnya. Dalam proses pembelajaran di kelas kontrol terlihat masih ada beberapa siswa yang tidak mengikuti pembelajaran dengan serius dibuktikan dengan adanya siswa yang membuat mainan pesawat-pesawat dari kertas sehingga mengganggu proses pembelajaran yang berlangsung. Hal ini menunjukkan bahwa siswa di kelas kontrol kurang aktif dibandingkan siswa di kelas eksperimen dalam proses pembelajaran, sehingga berdampak pada hasil belajar siswa di kelas kontrol lebih rendah dari hasil belajar siswa di kelas eksperimen.

Terdapat "Pengaruh Model Kooperatif Tipe Numbered Head Together (NHT) terhadap Hasil Belajar PKn Siswa di Kelas V SDN 15 Padang Sarai Kota Padang."

Pengujian hipotesis pada penelitian ini adalah untuk melihat terdapat atau tidaknya pengaruh model NHT terhadap hasil belajar siswa pada pembelajaran PKn.Setelah dilakukan uji normalitas dan uji homogenitas, diketahui nilai postest siswa pada kedua kelas sampel berdistribusi normal dan memiliki variansi yang homogen. Selanjutnya hipotesis mengenai pengaruh model NHT terhadap hasil belajar PKn siswa pada materi menjaga keutuhan NKRI diuji menggunakan statistik inferensial menggunakan rumus uji t.Berdasarkan uji-t yang dilakukan diperoleh $t_{\text {hitung }}=2,149$ dengan $t_{\text {table }}=1,67$. Karena $t_{\text {hitung }}>t_{\text {tabel }}$, maka tolak $\mathrm{H}_{0}$ dan terima $\mathrm{H}_{1}$.

Berdasarkan analisa data yang diperoleh setelah penelitian tersebut, maka hipotesisnya"terdapat pengaruh positif penerapan model kooperatif tipe NHT terhadap hasil belajar PKn siswa di kelas V SDN 15 Padang Sarai” yang terlihat pada perbedaan hasil belajar siswa yang diajar menggunakan model NHT dengan hasil belajarsiswa yang diajar menggunakan pembelajaran konvensional. Hal ini dapat dilihat pada tes akhir siswa yang diberikan kepada kelas eksperimen dan kelas kontrol.Dengan menggunakan model NHT pada kelas eksperimen hasil belajar siswa meningkat. 
Bimbingan guru yang mengarah siswa untuk aktif dalam pembelajaran serta mencari penyelesaian terhadap masalah, siswa belajar untuk menyelesaikan tugas-tugasnya.Sesuai dengan pendapat Sudjana (2009:22) menyatakan "hasil belajar adalah kemampuan-kemampuan yang dimiliki siswa setelah ia menerima pengalaman belajarnya."

Hasil belajar pada kedua kelas dapat dilihat pada tes hasil belajar yang dikerjakan siswa secara individu. Berdasarkan hasil analisa data hasil belajar diperoleh skor maksimal kelas eksperimen adalah 100 dan skor minimal adalah 61 sedangkan nilai rata-rata kelas eksperimen adalah 87,00. Skor maksimal kelas kontrol adalah 100 dan skor minimal adalah 50 sedangkan nilai rata-rata kelas kontol adalah 81,97. Dengan demikian dapat disimpulkan bahwa terdapat pengaruh positif penerapan model kooperatif tipe Numbered Head Together (NHT) terhadap hasil belajar PKn siswa di kelas V SD N 15 Padang Sarai.

\section{SIMPULAN DAN SARAN}

Berdasarkan hasil penelitian yang diperoleh setelah melakukan analisis dan pembahasan terhadap masalah yang telah dikemukakan dalam penelitian ini, diperoleh nilai rata-rata post-test kelas eksperimen yang menerapkan pembelajaran dengan model NHT adalah 87,00 dan nilai rata-rata post-test kelas kontrol yang menerapkan pembelajaran konvensional adalah 81,97. Berdasarkan hasil uji hipotesis menggunakan uji- $t$ ( $t$-test) dapat disimpulkan bahwa penerapan model kooperatif tipe Numbered Head Togeteher (NHT) berpengaruh positif terhadap hasil belajar PKn siswa di kelas V SDN 15 Padang Sarai Tahun Pelajaran 2017/2018.

Berdasarkan pembahasan yang telah diuraikan dapat dikemukakan beberapa saran sebagai berikut :(1)Diharapkan kepada guru PKn untuk dapat mencoba melakukan strategi mengajar yang bervariasi dalam pembelajaran PKn diantaranya menerapkan model NHT dalam proses pembelajaran.(2) Bagi kepala sekolah sebagai informasi dalam pembina personil guru dalam memberikan sumbangan yang positif untuk perbaikan proses pembelajaran.(3) Penelitian ini hanya meneliti hasil belajar siswa menggunakan model NHT dan pembelajaran konvensional. Untuk itu, disarankan pada peneliti selanjutnya untuk meneliti 
aspek-aspek lainnya.(4) Bagi peneliti yang lain berminat diharapkan mengadakan penelitian lanjutan dengan dapat mengantisipasi kendala-kendala yang terjadi. 


\section{DAFTAR RUJUKAN}

Boyannese, Rahman. 2012. Metode-metode Pembelajaran. (Online) http://rahmanboyannese.wordpress.com/2012/04/05/metode-metode pembelajaran.pdf . Diakses Tanggal 11 Januari 2017.

Shoimin, Aris. 2014. 68 Model Pembelajaran Inovatif dalam Kurikulum 2013. Yogyakarta: Ar-Ruzz Media.

Sudjana, Nana. 2009. Penilaian Hasil Proses Belajar Mengajar. Bandung: Remaja Rosdakarya.

Sugiyono. 2017. Metode Penelitian Kuantitatif, Kualitatif dan R\&D. Bandung: Alfabeta.

Taufik, Taufina \& Muhammadi. 2011. Mozaik Pembelajaran Inovatif. Padang: Sukabina Press.

Trianto. 2009. Mendesain Model Pembelajaran Inovatif-Progresif. Jakarta: Kencana. 